Köse, M.; Yıldız, A. / Sosyal Bilimler Araştırmaları Dergisi. I, (2012): 81-99

\title{
Tarih Eğitiminde Sosyal ve Kültürel Konuların Öğretimi
}

\section{Meliha Köse ${ }^{1}$, Abdullah Yıldız}

\begin{abstract}
Özet
Geleneksel tarih öğretiminin, siyasi olaylara odaklanması, tarih ders programlarında ve dolayısıyla ders kitaplarında daha çok yönetim ve savaş konularına ağırlık verilmesine sebep olmaktadır. Son yıllarda tarih öğretiminin amaç ve yöntemlerinin değişmesi, çeşitlenmesi, tarih ders programlarının ve ders kitaplarının bu bağlamda sorgulanmasını da beraberinde getirmiştir.

Postmodernist tarih yaklaşımı ile sıradan insanların hayatları tarih öğretimine taşınmaya başlanmıştır. Çünkü bu tarih anlayışı, tarihin sadece siyasi tarihten ibaret olmadığını, toplumun ve gündelik yaşam konularının da bu ders içerisinde hak ettikleri yeri almaları gerektiğini savunmaktadır. Bu doğrultuda kadın, erkek ve çocukların gündelik hayatlarının da tarihin konusu olarak görülmesi, tarih derslerinde sosyal ve kültürel konuların önem kazanmasına yol açmıştır. Böylece daha önce tarih ders kitaplarında ilgi görmeyen bu konular son dönemlerde değer kazanmıştır. Bu nedenle tarih öğretiminde sosyal ve kültürel konulara nasıl yer verileceği ve bu konuların ögretiminde nasıl bir yöntem değişikliğine gidilmesi gerektiği bir problem olarak karşımıza çıkmaktadır.
\end{abstract}

Anahtar kelimeler: Tarih Öğretimi, Sosyal ve Kültürel Konular, Postmodern Tarih Öğretimi.

\section{Teaching of Social and Cultural Issues in History Education}

\begin{abstract}
The traditional history teaching focusing on political events, gives more emphasis on management and the causes of war in the course of history curricula and textbooks. Changes and diversity in the objectives and methods of history teaching in recent years, brought curricula and textbooks into question in the respect of history.

With postmodernist approach to history, the lives of ordinary people started to be a subject in history teaching. Because of this approach, history does not consist only of political history but asserts society and everyday life issues to take their rightful place

\footnotetext{
${ }^{1}$ Dr. Tarih Öğretmeni, Tevfik İleri Anadolu İmam Hatip Lisesi, Ankara e-mail: melihakose@gmail.com

${ }^{2}$ Dr. Tarih Öğretmeni, Gazi İlköğretim Okulu, Ankara

e-mail: abdullahyildiz1956@gmail.com
} 
in this course. In this respect, as everyday lives of women, men and children seen as the subject of the history, social and cultural issues gain importance in history lessons. Thus, these issues not considered in history textbook before have been appreciated in recent years. For this reason, a problem arises how to deal with social and cultural issues and make appropriate changes in the teaching method of history.

Key words: History Teaching, Social and Cultural Issues, Postmodern History Teaching.

\section{GİRIŞ}

Geçmişin kültür ve medeniyetinden, geçmişte yaşamış insanlıktan bilgiler aktaran tarihin, bilimselliği tartışmalara konu olmuş, objektifliği sorgulanmıştır. Bilimsel tarih anlayışının ortaya koyduğu gerekliliklerden biri de tarihi bilgiye belgeler 1şı̆̆ında ulaşmaktır. Yusuf Akçura, Birinci Tarih Kongresinde, tarihte usule ve o usulün nasıl tatbik edilmiş ve edilmekte olduğuna dair bilgi vermek amaciyla verdiği konferansta, "Hepiniz bilirsiniz ki tarih binasının kerestesi, malzemesi, artık lisanımıza girmeye başlamış olan bir tâbir ile materyali vak'alar (Fait'ler) dır. Nasıl ki taşsız, ağaçsız, demirsiz bir ev inşa olunamazsa, vakıalar toplanmaksızın da bir tarih binası kurulamaz" cümleleri ile tarih ile belge arasındaki zorunlu bağa vurgu yapmaktadır. Tarihin nasıl yazıldığı kadar nasıl öğretildiği de tarihçiler arasında önemli tartışma konuları arasında yerini almıştır. Akçura, Fransa ve Almanya'da öğrencideki vatanseverlik duygusunun takviyesine yönelik tarih eğitiminin başka medeniyetleri ihmal ettiğinden ve Osmanlı Meşrutiyet dönemi tarih öğretiminde Fransız bakış açısının baskın olmasından yakınmıştır (Akçura, 1932). Aynı şekilde tarih öğretimi ile ilgili yakın dönem tartışmaları arasında yer alan "resmi tarih" eleştirileri, kolektif bir kimlik oluşturma kaygısı olarak değerlendirilmektedir. Ulus devlet anlayışının ise Fransız İhtilalı'nın etkisi olduğu düşünülmektedir (Bilgin, 1995: 113-114). Tarih öğretimine ilişkin geçmişte ve günümüzde yapılan eleştiriler tarih programlarına uzanmaktadır. Dolayısıyla tarih öğretiminin içeriği ilgili endişe ve eleştiriler tarih programlarının yeniden gözden geçirilmesini gerekli kılmıştır. Tarih öğretim programları düzenlenirken, tarih dersinin amaçları ve öğrencilerin ders sürecinde edineceği kazanımlar meselesi de beraberinde gelmektedir. Son yıllarda tarih öğretiminin amaçlarının ne olması gerektiği sıkça tartışılırken, tarih öğretiminin yeniden yapılandırılması da devam etmektedir. Bu yeniden 
yapılanma süreci doğrudan tarih ders kitaplarında da etkisini göstermektedir. Ancak Ortaylı'nın da belirttiği gibi nasıl bir tarih ders kitabının yazılacağ öğretimi için geniş, kalıcı ve devamlı bir problemdir (2007: 43).

İkinci Dünya Savaşı'ndan günümüze dünyada sosyo - ekonomik ve kültürel alanda meydana gelen değişime paralel olarak tarih öğretiminin amaçlarında da değişimler yaşanmıştır. Sosyo - ekonomik ve kültürel alanda yaşanan bu değişim, insanları daha nitelikli ve üretken olmaya zorlamıştır. $\mathrm{Bu}$ değişim neticesinde eğitim kurumlarına yeni görevler yüklenmiş ve eğitim kurumlarının görevleri gözden geçirilmiştir. İhtiyaçların ışı̆̆ı altında eğitim alanında yaşanan bu değişim, tarih öğretimini de etkilemiştir. Bu dönemde, özellikle İngiltere başta olmak üzere teknolojik ve demokratik açıdan gelişmiş ülkelerde tarih öğretiminin yeri, amaçları ve hedefleri tartışma konusu olmuştur (Demircioğlu, 2007: 20). Türkiye'de de halihazırda bu konular tartışılmakta ve çözüm yolları araştırılmaktadır.

Türkiye'deki tarih öğretiminin yapısına bakıldığında, olaylar arasında nedensellik bağıntısı kurmak, tarih öğretiminde birincil temel olarak alınarak tarih, sebep - sonuç ilişkisine indirgenmekte ve kaba bir pozitivist bilim yorumu yapılmaktadır. Öte yandan sebep - sonuç ilişkisi de keşfettirilmemekte, tersine öğretmen tarafından öğrencilere dikte edilmektedir. Avrupa ve Amerika'da ise tarih öğretimi, insanlığın başarılarının takdiri, kronoloji, benzerlik - farklılık, değişim -süreklilik, nedensellik, kaynak kullanımı, kanıt değerlendirme, tarihin yorumlanması, kültürel miras, demokrasi, insan hakları gibi temel kavramlar üzerine inşa edilmiştir (Safran, 2002: 177). Bu nedenle tarih öğretimi bir araç olarak değil tamamılla disiplinin mantığına uygun bir amaç olarak kullanılmalıdır. Böylece eleştirel düşünebilen ve tarihin, geçmişin tarihçiler tarafından yorumlanmasında doğruları arama çabasının yattığı bir bilim dalı olduğunu kavrayabilen öğrenciler yetiştirilebilir. Dolayısıyla tarih eğitimi demokratik bir toplumun gelişmesinde dersler vermeyi garanti etmesi gereken tahminci bir alan değildir. Bununla birlikte, tarih dersinin, bireylerin bilişsel gelişimine katkıda bulunan (Lee, 1984; Akt.: Dilek, 2001: 334) ve onların güncel dünyayı anlamada farklı bakış açılarına sahip olmasına yarayan bir öğretim alanı olarak okul programında yer alması gerekmektedir (Dilek, 2001: 334).

Tarih öğretiminin amaçları yaşanan olaylar ve beklentilerin değişmesiyle ülkeden ülkeye, zamandan zamana değişim göstermiştir. Önceki yüzyıllarda insanlığın tarihi birikimini yeni nesillere aktarmak tarih öğretiminin 
önemli bir amacı iken günümüz tarih öğretiminde öğrencilere problem çözme ve düşünme becerileri kazandırma gibi amaçlar önem kazanmaya başlamıştır. $\mathrm{Bu}$ bağlamda genel anlamda tarih öğretiminden beklenen amaçları şöyle sıralamak mümkündür:

- Tarihsel bilgiyi, toplumsal değerleri ve kültürü aktarmak,

- Ülkelerin ideolojik yapılarının öğrenciye benimsetilmesi ve kimlik gelişimi,

- Öğrencilere bilimsel düşünme becerilerini kazandırmak,

- Geçmişi, bugünü ve geleceği anlamak ve bu üç zaman dilimi arasındaki ilişkiyi kavratmak,

- Tarihin temel kavramlarının bilgilerini vermek,

- Dil becerilerini artırmak ve boş zamanlarını değerlendirmenin aracı olarak tarih öğretimi (Demircioğlu, 2010: 66).

Köstüklü (2001: 18) ise, tarih öğretiminin genel amaçlarını şu şekilde siralamaktadır:

- Öğrencinin geçmişe alakasını çekmek,

- Öğrencinin diğer ülkeleri ve kültürleri bilmesine ve anlamasına katkıda bulunmak,

- Geçmişin 1şığında günümüzü anlamak,

- Programın diğer alanlarını zenginleştirmek,

- Disiplinli çalışma ile zihni eğitmek,

- Öğrencileri yetişkin hayata hazırlamak,

- Öğrencinin kimlik duygusunun gelişimine katkıda bulunmak.

Yukarıda bahsedilen amaçların gerçekleşmesinin yansıması olarak Barton ve Levstik (2004: 7), çocukların tarih öğrenimleri sonucunda aşağıdaki dört amacı gerçekleştirebilmeleri gerektiğini belirtmişlerdir:

1. Geçmişte kalan insanlar ve olaylarla kendileri arasındaki bağlantıları belirlemek / keşfetmek,

2. Geçmişteki olaylar arasındaki nedensel bağları ortaya koyacak biçimde analizler yapmak,

3. Tarihteki insanlara ve olaylara karşı etik değerlere uygun tepkiler göstermek,

4. Tarihe ilişkin öğrendiği bilgileri göstermek ve kullanmak. 
Görüldüğü gibi, tarihin değișen amaçları, öğrenciyi sadece bilgiyi alıcı pozisyonunda görmek istememektedir. Öğrencinin tarihi bilgiye ulaşmanın yollarını da öğrenmesi beklenmektedir. Bu beklenti öğrenciyi pasif alıcı durumdan çıkararak aktif alıcı ve hatta üretici duruma taşımaktadır. Öğrencinin pasif alıcı olmaktan kurtulması ise tarih öğretiminde içerik ve yöntem değişikliği ile doğrudan ilişkilidir.

1970'li yıllarda sanayi toplumu olmanın uzantısı olarak matematik bilimleri değer kazanırken, sosyal bilimler ve buna bağlı olarak tarih öğretiminin gerekliliği sorgulanma sürecine girmiştir. Ancak tarih derslerinin kronolojik bir bilgi sunmaktan öteye, karar verme, problem çözme gibi zihinsel becerileri de geliştirdiği savunularak, tarih ders programları bu doğrultuda yapılandırılmaya çalışılımıştır. Tarih öğretim programlarının toplumdaki pek çok değişkeni (şiddet, gelir dağılımı eşitsizliği, cinsiyet ayrımcılığı, çevre sorunları vs.) dikkate alarak hazırlanması beklenmektedir. Özellikle erkek merkezli bakış açısının hakim olduğu tarih öğretim programları kız öğrencilerin ilgisini yeterince çekmemektedir (Safran, 2008: 14-15). Bu bağlamda tarihin ilgilendiği konuların kapsamı ve çeşitliliğinin artması söz konusudur (Tekeli, 2002: 7).

Köse (2004: 62) tarafından yapılan "Tarih Öğretiminde Kadın ve Türk Kadını İmajı” adlı çalışması sonucunda hem öğrencilerin hem de öğretmenlerin tarih öğretiminde savaşlar ve yıkılan kurulan devletler diye ifade ettikleri siyasi tarihten öteye daha farklı konuları görmek istedikleri ortaya çıkmıştır. Özellikle öğretmenler sanat, spor ve kültürel alanda başarılı kadınların hikayelerinin öğrencilere örnek olabileceğini ifade etmişlerdir. Öğretmen ve öğrencilerin ifadeleri, tarih öğretim programlarından beklentilerin değiştiğini ortaya koymaktadır. Bu durum, aynı zamanda hem öğretmenlerin hem öğrencilerin tarih ders kitaplarında savaşların ve siyasi olayların ötesinde bilgilere ulaşma isteklerine işaret etmektedir. Öğrenci kendi ailesinin, kendi çevresinin içinde yer aldığı toplulukların tarihini öğrenebilme firsatlarına sahip olmalıdır. Her öğrencinin farklı olan bu bilgileri büyük ölçüde kendisinin kurması gerekecektir. Öğrenci kendisini bir yandan yakın çevresiyle ilişkilendirirken, öte yandan kendisini ve yaşadığı yerelliği, ülkesi ve dünyası içinde bir yere yerleştirecektir (Tekeli, 2002: 15-16). Bu nedenle sosyal ve kültürel konuların öğretimi büyük önem arz etmektedir. "Sosyal ve kültürel konuların öğretimi” şu iki boyutuyla irdelenmelidir: 
- Tarih öğretiminin değişen amaçlarına paralel olarak tarih öğretim programlarında sosyal ve kültürel konuların yeri ne olmalıdır?

- İkinci olarak sosyal ve kültürel konuların öğretilmesinde kullanılacak yöntemler nasıl olmalıdır?

\section{“SOSYAL VE KÜLTÜREL KONULAR" VE TARIH PROGRAMI}

"Tarih, geçmişin bilimidir." tanımını kötü bir ifade tarzı olarak niteleyen Marc Bloch, geçmişin olduğu haliyle bilimin nesnesi olamayacağını söylemektedir (Bloch, 1994: 17). Ona ve diğer Annales Okulu temsilcilerine göre tarihin nesnesi, doğası gereği insanlar, insan toplumlarıdır (Bloch, 1994: 19). Yirminci yüzyılın ikinci yarısında toplumsal tarih konusu popüler hale gelmiştir. Toplumsal tarih terimi birbirleriyle ilişkili olarak üç farklı anlamda ele alınmıştır: 1. Aşağı ve yoksul sınıfların tarihi (toplumsal hareketler), 2. Davranışlar, gelenekler ve günlük yaşam gibi terimler dışında sınıflandırılmaları güç olan insan etkinlikleri üzerine yapılan çalışmalar, 3. "Toplumsal" sözcüğü ile bir arada kullanılan iktisadi tarih (Hobsbawn, 1985: 146). Toplumsal tarihe yüklenen bu farklı anlamlar önceden tarihin ilgi alanına girmeyen pek çok konuya dikkat çekmiştir.

Lucien Febvre ve Marc Bloch'un 1929 y1lında kurdukları Annales Okulu Fransa'da tarihe yeni ve geniş çerçeveli bir bakış getirmiş, kişinin toplumsal yaşamının bütün yönleriyle tarih kapsamına alınması yönündeki çalışmalara bir hayli mesafe kazandırmıştır. Fernand Braudel ve Le Roy Ladurie gibi temsilcilerinin yönlendirmesiyle, toplumun her türlü hâlinin (geçimi, açlığı, hastalı̆̆ı, evliliği, öğrenimi) ve doğa ile ilişkisinin tarihin konuları arasına katılmasına çalışılmıştır (Çapa, 2009: 128; Halkın, 2000: 117).

Dünyada tarih eğitimini şekillendiren anlayışların büyük ölçüde, dönemin hâkim siyasal / felsefi düşünce akımlarına paralel gelişme gösterdiği bilinen bir gerçektir. Tarih yazımı ve eğitimini belirleyici faktörler eskiçağda devlet formlarıyken Ortaçağda din, modern çağda ulusçuluk, günümüzde ise küreselleşmenin düşünsel arka planı olan çok kültürlü/postmodernist yaklaşımlar olmuştur (Şimşek, 2007: 10). Peki postmodernist yaklaşımların tarih öğretimindeki etkisi ve yeri nedir?

Postmodernizm, akademik bir alan olarak tarih biliminin seyrettiği yönü değiştirmiştir. Brown'a (2005) göre bu değişim yedi durumda gerçekleşmiştir. Birincisi, postmodernizm tarihsel araştırmanın metotlarını değiştirmiştir. Dile, tarihçinin öznelliğine ve tarih yazım biçimine yeni bir duyarlılık katmıştır. 
Postmodernizm, tarihin yönünü sosyal bilim metotlarından sanat ve beşerî bilimlerin metotlarına doğru değiştirmiştir. İkincisi, postmodern teori tarih biliminin gündemini değiştirmiş̧ir. Popüler kültür, kişisel tanıklık, ikinci el kaynaklarla çalışmanın yeniden yapılandırılması ve metinlerin yapıbozumu (deconstruction) gibi yeni alanlarda çalışma yapılmasına öncülük etmiş ve bu çalışmaların yoğunluk kazanmasını sağlamıştır (Akt.: Yıldız, 2010: 70). Üçüncüsü, postmodernizm, tarih öğretim metotlarını değiştirmiştir. Daha önceleri öğrenciler tarih konularının alıcısı konumundadır ve onlara aktarılan konular sosyal bilim olarak tarih ile sınırlandırılmıştır. Postmodernizmle birlikte konuların genişliği ve çeşitliliği artmış, takip edilen yol ve yöntemler zenginlik kazanmıştır (Brown, 2005; Akt.: Yıldız, 2010: 71). Postmodern tarih öğretimiyle birlikte öğrenci, ders kitapları başta olmak üzere birinci ve ikinci elden kaynaklara, kendisine sunulan her şeye şüphe ile bakmayı öğrenmektedir (Southgate, 1996; Akt.: Karabağ, 2002: 66). Öğrencinin eğitim sistemi içerisinde aktif bir pozisyon almasının ve öğretmenin ona rehberlik etmesinin gür bir sesle ifade edildiği günümüzde postmodernist eğitim anlayışıyla örtüşen bir anlayış sergilenmektedir. Karabağ'ın (2002: 66) ifadeleriyle bu görüş somutlaşmaktadır. Ona göre, bilgi çağı olarak da adlandırılan postmodern dünya içinde çocukların hedeflenen becerileri sağlayabilmeleri ve kendi kimliklerini oluşturabilmeleri için, okul ve sınıf ortamının teknolojinin gereklerine uygun araç-gereçlerle donatılması lazımdır. Çocuk ne kadar çok öğretim materyali ile uyarılırsa o kadar çok düşünmeye ve öğrenmeye istek duyacaktır. Tarih öğretmenin ise sinıfta her öğrenciyi aktif hâle getirmesi ve bütün doğru bilgilerin tek adresi gibi değil de bilgiye ulaşmanın yolunu gösteren bir rehber olarak hareket etmesi, postmodern programın ruhuna uygun olacaktır. Dördüncüsü, postmodernizm tarih disiplininin genişlemesini sağlamıştır. $\mathrm{Bu}$, daha fazla disiplin içi bir tutum sergilenmesini, sosyal antropoloji, etnoloji, dil çalışmaları, edebiyat ve hatta felsefe gibi alanlarda çalışmalar yapılması konusunda yeni fikirlere açık olmayı sağlamıştır. Beşincisi, postmodernizm, tarih alanını birçok bölüme, ilgi grubuna ve zıt kamplara bölmüştür. Altıncısı, postmodernizm, yazılacak olan tarih kitaplarının üst anlatılarının kabulüne müdahâlede bulunmuştur. Yedincisi, postmodernizm, tarih alanındaki profesyonelliği çok büyük ölçüde canlandırmıştır. Bu alandaki çalışmalara katılma ya da yeni fikirleri reddetme noktasında heyecana ve düşünmeye neden olmuştur (Brown, 2005; Akt.: Yıldız, 2010: 71). 
Modernist tarih, geçmiş hakkındaki bilgilerin, neden-sonuç ilişkisi içerisinde, objektif olarak aktarılması şeklinde ifade edilirken postmodernizmde tarih, yaşanmış pek çok kişisel hikâyenin tarihçi tarafından yeniden yorumlanması olarak görülmektedir (Jenkins, 1994; Akt.: Karabağ, 2002: 65).

Postmodern tarih eğitimine göre tarih, geçmişi genelleyerek ve ilkelendirerek anlatmamalıdır. Bunun yerine mikro anlatımlara geçmelidir çünkü herkesin yaşadığı önemli ve anlamlıdır (Sönmez, 2008: 133). Bu nedenle postmodern tarih öğretim programı sadece kralların, komutanların, ünlülerin, erkeklerin, beyazların ya da Avrupalıların değil herkesin tarihine saygı duymayı ve yer vermeyi öngörür (Husbands, 1996; Akt.: Karabağ, 2002: 65). Postmodern tarih anlayışı "birey olarak insan"a daha çok vurgu yaptığı için tarihin konu alanını değiştirmeye başlamıştır. İnsanların gündelik hayatları en az siyasi olaylar kadar öğretilmeye değer görülmeye başlanmıştır. Tarih, sadece yönetimdeki ve savaşlardaki güçlü insanlarla değil; kadınlar, çocuklar ve sıradan erkeklerle de ilgilenerek herkesi içine almaya çalışmaktadır. Avrupa eğitim sisteminin çoğunda siyasi ve diplomatik konuların yanı sıra sosyal, kültürel ve entelektüel tarih konularının öğretilmesine yönelik eğilim dikkat çekmektedir (Dilek, 2010:145).

Avrupa Konseyi Bakanlar Komitesi'nin “21. Yüzyıl Avrupa'sında Tarih Öğretimi” başlıklı tavsiye kararında "Avrupa tarihi, sadece siyasal olarak değil her boyutta, ekonomik, sosyal ve kültürel olarak da incelenmelidir." denmiştir (URL 1, 2001). Artık birçok ülke programını bu doğrultuda yeniden düzenlemektedir. Tarih ve tarih öğretimi üzerine yapılan bütün bu tartışmalar tarih programları üzerinde etkilerini hissettirmeye başlamıştır. $\mathrm{Bu}$ durumu Avrupa'daki programlarda görülmektedir. Avrupa'da 20. yüzyıl tarihiyle bağlantılı gelişen temalara yer veren program sayısı gittikçe artmaktadır. Tarih programlarında en sık rastlanan "gelişme temaları" şöyle sıralanmaktadır: 20 . yüzyılda teknolojik ve bilimsel gelişmeler, Özellikle sıradan insanların hayatı açısından sosyal değişim, Kadınların toplum içinde değişen rolleri, Kitle kültürünün ve gençlik kültürünün ortaya çıkış1, 20. yüzy1lın özgün kültür ve sanat akımları, Sanayileşme ve sanayi sonrası toplumların ortaya çıkışı, Kentleşme, Ulaşım ve haberleşme, Nüfus hareketleri, Avrupa'da ulusal ve diğer azınlıkların değişen durumları, Çatışma ve işbirliği, Milliyetçi hareketler, Totalitarizm ve liberal demokrasi, İnsan hakları (Stradling, 2003: 4). 
Yukarıdaki temalardan anlaşıldığı gibi, Avrupa tarih programlarında siyasi tarih konularından sosyal ve kültürel konulara doğru yönelme söz konusudur. Ayrıca, ABD'de "The Social Studies" dergisinin 1992'den beri yayımladığı sayılarında yer alan çok sayıdaki makalede, çocuk edebiyatı ürünlerinden sosyal konuların öğretiminde (göç, kölelik, çok kültürlülük, soykırım başka kültürleri tanıma, savaş vb.) yararlanılmasını vurgulayan örnekleri sunulmuştur. Yine son on yılda, "Social Education" adlı süreli yayında ise tarih öğretimi, sosyal çalışmalar içerisinde miras, sosyal adalet, Batı Afrika kadınları, tarihte kadınlar ve hakları, Afrika Edebiyatı, çocuk işçiler konularının işlendiği tespit edilmiştir (Şimşek, 2006: 133, 134).

Tarihi kahramanların hayatlarını, savaşları, fetihleri ve siyasal krizleri incelerken tarihleri belirlemek, olayları sıralamak, neden ve sonuçlarını saptamak kolaydır; ama sosyal ve kültürel tarihi incelerken bunu yapmak çok zordur. Kültürel modeller ve gelişmeler kolayca olaylara ve durumlara ayrılamaz. Çoğu durumda kültürel süreçler konjonktüreldir, derin ve yavaş bir değişim gösterir. Siyasi tarihte çoğunlukla aktörler önemli yer tutarken, kültürel ve sosyal tarihte ise aktörlerin rollerini oynadığı sahne önem kazanır. Kültürel tarihte gelişmeleri bir bağlama oturtmaya çalışmak, neden ve sonuçların izini sürmek ikinci planda kalırken, belirli kültürel ve sosyal gelişmelerin o dönemde yaşayan insanlar için ne anlam taşıdığ 1 önem kazanmaktadır (Stradling, 2003: 75). $\mathrm{Bu}$ nedenledir ki sosyal ve kültürel konuları içeren bir program hazırlanırken öğrenci için sevilen, ömür boyu insan yaşamına anlam katan bir etkinlik olarak görülmesi sağlanmalıdır. Program tarih biliminin günümüzde kazandığı konu, ölçek, yaklaşım çeşitliklerini öğrenciye sergileyebilmelidir (Bkz.: Tekeli, 2002: 22). Sosyal ve kültürel konuların öğretimi dikkatleri, aktörlerden çok olayların yaşandığı mekana ve zamana yöneltmektedir. Tarihin yaşandığ1 mekanı ve zamanı anlamak ve yorumlayabilmek, insanlığın kendini anlamasında ciddi bir adımdır. Sosyal ve kültürel konuların geçiştirilmeden programlarda verilmesi, programlarda önemli bir eksikliğin giderilmesi anlamına gelmektedir.

\section{SOSYAL VE KÜLTÜREL KONULARIN ÖĞRETIMI}

Sosyal ve kültürel konulara eğilim tarih derslerinde olduğu gibi sosyal bilgiler öğretiminde de hissedilmektedir. ABD'de NCSS'nin on tema altında açıkladığı sosyal bilgiler programının standartları buna örnek olarak gösterilebilir. NCSS bu temaları 'Kültür', 'Zaman, Süreklilik ve Değişim', 'İnsanlar, Yerler ve Çevreler', 'Bireysel Gelişim ve Kimlik', 'Bireyler, Gruplar 
ve Kurumlar', 'Güç, Yönetim ve Toplum', 'Üretim, Dağıtım ve Tüketim', 'Bilim, Teknoloji ve Toplum', 'Küresel Bağlantılar', 'Vatandaşlık Amaçları ve Uygulamaları' olarak belirlemiştir. Bu öğrenme alanları ve öğrenme alanları ile ilgili açıklamalar incelendiğinde sosyal bilgiler ile kültür arasındaki ilişki görülmektedir. Sosyal bilgiler dersi ile öğrencilere kazandırılacak bilgi, beceri, değer ve sosyal katılıma ilişkin amaçlar incelendiğinde bu amaçlara ulaşabilmek için sosyal bilgiler dersinde kültürel öğelerden yararlanmak gerektiği söylenebilir (Deveci, 2009: 2). Türkiye'de 2004 yılında uygulamaya konan sosyal bilgiler programının öğrenme alanları belirlenirken de bu temalardan yararlanılmıştır. Bu programda yer alan öğrenme alanları bir ya da birden fazla akademik disiplini içerebilmektedir. Örneğin; "Birey ve Toplum," psikoloji ve vatandaşlık bilgisini; "Kültür ve Miras", antropoloji, tarih ve vatandaşlık bilgisini; "İnsanlar, Yerler ve Çevreler," coğrafya'yı; "üretim, tüketim ve dağıtım" ekonomi’yi; "Gruplar, Kurumlar ve Sosyal Örgütler" ve "Güç, Yönetim ve Toplum" sosyoloji'yi; vatandaşlık bilgisini, hukuku içermektedir. "Bilim, Teknoloji ve Toplum" ve "Küresel Bağlantılar" disiplinler aras1 alanlardır (MEB, 2012). Bu öğrenme alanlarının bir ya da birden fazla akademik disiplini içermesi sosyal ve kültürel konuların program içerisindeki ağırlığını göstermektedir. Aynı şekilde tarih öğretiminin değişen amaçlarına paralel olarak sosyal ve kültürel konulara olan yönelme devam edecek gibi görünmektedir. Tarih programında sosyal ve kültürel konuların önemli hale gelmesi, bu konuların öğretiminin nasıl olması gerektiğini de sorgulamaya ve tartışmaya açmıştır.

Yaşça küçük olan çocuklarda tarih konusunda araştırmacı bir ruh kazandırabilmek için, onları soyut, politik, anayasal ve dinsel değişimleri anlamaya zorlamaktan çok onlara yazı, evler, eğlence, giyim, ulaşım gibi somut konuların öğretilmesi daha uygundur (Safran, 2006: 25). Zira Piaget'ye göre bilişsel gelişimin son evresi olan soyut işlemler evresinde ancak çocuklar soyut düşünebilmekte, bilimsel yöntemle problem çözebilmektedir (Senemoğlu, 2002: 46). Bu çerçevede bir araştırma yapan Hallam'a göre, birçok orta öğretim öğrencisi karşısına tarih dersi öğrenilmiş gerçeklerin ezberlenmesinden farklı bir disiplin olarak çıktığında soyut işlemler evresine uygun cevaplar verememektedirler (Dilek; 2002: 69). Hallam'ın bu bulgusu, “Gençlerin Tarih Anlayışında Soyut Kavramlarla Düşünme Kapasitesi” adlı araştırmasında bu tür bir kapasitenin 15 yaşından önce genellikle pek az gelişmiş olduğunu söyleyen S.K. Stones tarafından da desteklenmiştir (Safran; 1996: 4). Çocuklarda soyut 
kavramlarla düşünme kapasitesinin 15 yaşından önce genellikle pek az gelişmiş olduğunu belirten görüşler göz önünde bulundurulduğunda, tarih öğretiminin soyut olaylara dayandırılarak anlatılması, öğrenilen bilgilerin kalıcı olmaması, çocuğun soyut bilgileri gerçek hayat ile ilişkilendirememesi ve tarih derslerinin gereksiz ve sıkıcı algılanması sonuçlarını beraberinde getirecektir. Tarihi bilgilerin yakından uzağa, somuttan soyuta doğru verilmesi bu açıdan oldukça önemlidir. Tarihi kendi çevresinden başlayarak sorgulayan bir birey tarihe adım adım ilerlerken, elde ettiği somut verilerin üstüne soyut bilgileri daha rahat yerleştirebilecektir. Sosyal ve kültürel konuların öğretimi tarihin bu yanını desteklemeye oldukça müsaittir. Özellikle Türkiye açısından düşünüldüğünde tarihin kültürel boyutuna ulaşmak çok zor değildir. Zengin kültürel mirasa sahip bu ülkede örnek olarak kullanılacak kaynak/malzeme sorunundan ziyade, tarihi kaynakların görülmemesi ve derslerde kullanılmaması sorunu vardır.

Tarih programlarında çoğunlukla öğretmenlere, ne öğreteceği ile ilgili değil, nasıl öğreteceği ile ilgili esneklik bırakılmaktadır. Öğretmenlerin pek çoğu yoğun ders programlarından yakınmaktadır (Stradling, 2003: 69). Türkiye'de de yoğun tarih ders programlarının içeriğini ağırlıklı olarak siyasi tarih konuları oluşturmaktadır. Tarih öğretimine yönelik beklentilerin çeşitlenmesi ile birlikte, sosyal ve kültürel konuların tarih öğretim programlarındaki yer alma durumu tarih öğretiminin problemleri arasında yerini almıştır. Liselerde okutulan 2007 tarihli "Tarih 1" ders kitabında kültür ve medeniyet konusu şu başlıklar altında verilmektedir:

- Devlet yönetimi

- Din ve inanış

- Sosyal ve iktisadî hayat

- Yazı, dil ve edebiyat

- Bilim ve sanat

2011 tarihli ve halihazırda okutulan 9. sınıf tarih ders kitabından kültür ve medeniyet konuları siyasi tarih konularının içinde verilerek ayrı bir başlık olarak verilmemiştir. Siyasi tarihle iç içe verilmesi uygun görülmüştür (Komisyon, 2011). Öğretim programlarında veya ders kitaplarında yukarıda değinilen alt başlıklar altında verilen konuların işlenişinde daha çok ders kitaplarında verilen yazılı ve görsel kaynakların sorgulanmasına ağırlık verilmektedir. Sosyal ve kültürel konuların öğretiminde kaynaklara yönelik 
sorgulamaların, tarihi ezber dersi olmaktan kurtardığı düşünülebilir fakat bunun yeterli olduğu iddia edilmemelidir.

Hem siyasi hem de sosyal ve kültürel konuların öğretiminde farklı öğretim yöntemlerinin bir arada kullanılması kaçınılmazdır. Anlatım, örnek olay çalışması, soru sorma, grup çalışmaları, alan ve müze gezileri, benzetişim (simülasyon) tarih öğretimi için uygun görülen metotlardan bazılarıdır (Köstüklü, 2001: 33). Ayrıca gelişen teknolojinin sağladığı olanaklar ile internet, sosyal ve kültürel konuların öğretiminde kullanılabilir. İnternet üzerinden sağlanabilecek çok sayıda yazılı, sesli ve görsel materyal zengin bir kaynak yelpazesi oluşturabilir. Ayrıca geçmişe tanıklık etmiş kişilerle yapılmış sözlü tarih çalışmaları, sosyal ve kültürel konuların öğretiminde önemli bir yere sahip olmalıdır (Stradling, 2003). Bu metotlar öğretmenin bilgisi ve hayal gücü oranında geliştirilebilir. Ancak öğretmene sunulacak yardımcı kaynaklar da öğretmene büyük kolaylık sağlayacaktır. Özellikle sınıf dışı öğretimi hedefleyen alan gezileri için iyi bir planlama gerekmektedir.

Fischer (1993: 3), simülasyonların öğrencileri geçmişte meydana gelen olayların neden ve sonuçlarını öğrenmeleri konusunda motive edeceğini belirtmektedir. Tim Bailey (2008), "Civil War" adlı eserinde simülasyonlar geniş ölçüde etkin öğretim stratejilerini içinde barındırmaktadır. Bunlar sayesinde öğrenciler, zengin ve derinlemesine bir tarihsel anlama ulaşmaları söz konusu olmaktadır. Richard Di Giacomo (2009), da simülasyon uygulamasından sonra öğrencilerin çoğunun kendisine, "Tarih dersi ilk defa benim ilgimi çekti." dediklerine şahit olduğunu ifade etmektedir. Simülasyon ve örnek olay çalışmalarında ise bilgisayar teknolojisinden yararlanmak tarihi görselleştirerek öğrenciye bilginin yakınlaştırılmasını sağlamak açısından önemlidir. Sosyal ve kültürel konuların öğretiminde ise görsel malzemelerin kullanılması kaçınılmazdır. Kitaplarda yer alan resim ve fotoğraflar bu konuları görselleştirmekte çok yetersiz kalmaktadır.

Sağlıklı ve kalıcı bir öğrenmenin gerçekleşmesinde öğrencinin yaparak ve yaşayarak öğrenmesinin gerekliliği görüşü önem kazanmıştır. Bu görüş yerel tarih öğretimine ilgiyi artırmaktadır. Yerel tarih insanların yakın çevresindeki tarihle ilgilendiği için, yaşanılan çevrede bulunan tarihi motif ve kalıntılar tarih öğretiminin materyalleri arasında yerini almaktadır (Demircioğlu, 2007: 71). Sosyal ve kültürel konuların öğretimi açısından yerel tarih konusu ele alınacak olursa çevrenin ciddi oranda öğretici malzeme ve örnek sunduğu fark edilebilir. Çevremizin ciddi oranda bize malzeme sunduğunu fark ederiz. Öğrencilerin 
yaşadıkları şehirde karşılaştıkları yer adları, eski binalar, kütüphaneler ve arşivler, ailelerin ellerinde bulunan belgeler, tablolar, portreler, gravür ve fotoğraflar, arkeolojik kalıntılar, tarihi yollar vs. tarih öğretiminin hizmetine sunulabilir. Bu yolla tarih öğrenen öğrenci, doğrudan etkileşimde bulunabildiği tarih ortamlarında hem yaparak ve yaşayarak tarih öğrenecek hem de öğrenmesi zor olan pek çok kavram, beceri ve bilgiyi elde etme imkânı bulacaktır.

Tarih öğretmenleri çoğu zaman, sözlü ifadelerinde güncel olaylar ile geçmiş olaylar arasında bağlantı kurmaktadır. Kimi zaman benzetme, kimi zaman karşılaştırma şeklinde gerçekleşen bu bağlantı kurma, "analoji” olarak ifade edilmektedir. Analoji ile bilinen şimdiki zaman ve bilinmeyen geçmiş zaman arasında sözlü ifadelerle ilişkiler kurulmaktadır. Analojinin, öğrencilerin karşılaştırma becerisinin geliştirilmesine ve tarihsel kavramaya yardımcı olacağ 1 düşünülürken bu yöntemin faydalı olmadığını düşünen tarihçiler de bulunmaktadır. Ancak bu karşılaştırmaların kendi şartları içinde değerlendirilerek yapılması ve uygun dile çevrilmesi sorunu konuyu hassas hale getirmektedir (Ata, 2008: 302).

Tarih öğretiminde, öğrencilerin en fazla problem yaşadıkları konulardan biri de kavramlardır. Bazı öğrenciler, özellikle soyut kavramları öğrenmekte büyük problem yaşamaktadırlar. Özellikle sosyal ve kültürel konularda öğrencinin karşılaştığı kavram sayısı oldukça fazladır. $\mathrm{Bu}$ kavramların öğretiminde kullanılacak analojiler, kavram öğretiminde kolaylık sağlayacaktır. Örneğin; Sadrazam= Başbakan, Reis'ülküttab= Dışişleri Bakanı, Defterdar= Maliye Bakan1, Divan-1 Hümayun= Kabine

Yukarıda verilen kavram karşılaştırması ile örnekler, öğrencinin dünyasında soyut kalan kavramları, günümüze yakınlaştırarak anlama olanağ 1 sağlayabilir (Demircioğlu, 2007: 47) Analoji yapılan konuların kendi şartları içinde değerlendirilmesine ve uygun ifadelerle anlatılmasına dikkat edilerek, sosyal ve kültürel konuların öğretiminde kullanılması söz konusu olabilir. Örneğin ekonominin anlatıldığ 1 konularda eskiden beri kullanılagelen paraların resimlerinin karşılaştırılması öğrencide bir fikir oluşmasını kolaylaştırabilir. Ya da müze gezileri sırasında eski devirlerde kullanılan eşyaların bizzat görülerek incelenmesi, öğrenciye eski ile yeniyi karşılaştırma imkânı vererek ve gözlem yaparak insanın tarihi seyir içerisinde sosyal ve kültürel alanda geçirdiği değişimleri fark edebilmesini sağlayabilir.

Tarih öğretmeni iki farklı kültürün izlerini taşıyan mimari eserleri göstererek, öğrencilerden karşılaştırmasını isteyebilir. $\mathrm{Bu}$ yolla öğrenci 
karşılaştırma yaparken hem dikkatle gözlem yapmayı, hem de görsel materyalleri kullanarak bilgiye ulaşmayı öğrenecektir. Ancak öğrenciye karşılaştırma yapılacak unsurları sunmak için öğretmen öğrenciyi yönlendirecek soruları önceden hazırlamalıdır. Yine aynı şekilde Osmanlı minyatür sanatını ve Rönesans dönemi resim sanatını karşılaştırmak yoluyla, iki resim sanatının farklılıkları ve ayrıntıları değerlendirilebilir. Öğrenci hem minyatür sanatı hakkında hem de Rönesans dönemi resim sanatı ile ilgili kalıcı bir fikre ulaşılabilir. Öğrencide bu konulara karşı ilgi uyandırmak daha kolay olabilir. Karşılaştırılan konular ile ilgili öğretmen ve öğrenciler tarafından hazırlanacak resimler, projeler ve maketler sınıf içinde sergilenebilir.

Türkiye'de müzeler aracıllğ̆ ile yapılan tarih öğretimini öğrenciler ilgi çekici bulmasına rağmen tarih öğretmenleri, müzelerden oldukça az yararlanmaktadır. Bunun nedenleri arasında öğretim programları, kalabalık sınıflar, ekonomik nedenler, mali kaynakların yetersizliği vs. yer almaktadır. Türkiye'de diplomatik ve askeri ağırlıklı tarih öğretimi anlayışı ve öğretim programlarının bu yönde işe koşulması, müzelerin tarih öğretiminde kullanılmasını arka plana itmiştir. Arkeoloji, sanat ve estetik eğitimi, folklor eğitimi çerçevesinde algılanan müzeler, tarihin öğretiminin hizmetine sunulmakta geç kalınmıştır (Ata, 2002: 14). Tarih öğretiminin yeniden yapılandırılması sürecinde kültür, sanat ve sosyal konuların gereken ölçüde programlarda yer alması, sorunun aşılmasında önemli bir basamak olmakla birlikte, tek başına yeterli değildir. Müzelerin tarih öğretiminde kullanılması için, öğretmenlerin eğitim sorunu ve konu ile ilgili yasal güçlüklerin de halledilmesi gerekmektedir. Bütün güçlüklerine rağmen müzelere dayalı eğitimin, geleneksel sınıf içi eğitime oranla daha kalıcı olduğuna dair çalışmalar bulunmaktadır (Ata, 2002: 16).

Tarih öğretiminde drama yöntemi, siyasi ve kültürel olayların kaynaştırılarak öğretilmesine imkân sağlayabilecek önemli bir etkinliktir. Tarihi gerçeklere uygun şekilde yazılmış bir senaryo, hikâye, parodi öğrenciler tarafından sergilenebilir. Bu yolla öğrenciler edinecekleri kişisel becerilerin yanı sıra, hem siyasi olayları anlamaya yaklaşacaklar hem de dönemin kültür unsurlarını fark edebileceklerdir.

Sosyal ve kültürel konuların öğretiminde kullanılacak etkinliklerden biri de tarih bulmacalarıdır. Örneğin Osmanlılarda devlet yönetimine ilişkin bir bulmacayı öğretmen kendi hazırlayabileceği gibi, öğrencilere de hazırlatabilir. Bulmacayı hazırlayan veya sınıfta bulmacayı çözen öğrenciler eğlenerek 
Köse, M.; Yıldız, A. / Sosyal Bilimler Araştırmaları Dergisi. I, (2012): 81-99

kültürel konularda bilgilenebilirler. Ayrıca konulara uygun seçilmiş karikatürler, grafikler, kavram haritaları da, tarih derslerinin sıkıcı ve ezber dersi olduğuna ilişkin yargıları ortadan kaldıracaktır. Yukarıda bahsi geçen yöntemler, öğrenci merkezli tarih öğretimini ön plana çıkarmaktadır. Fakat bu yöntemlerin uygulanabilirliğini sağlamak, tarih öğretmenlerinin bu yönde eğitilmesini gerektirmektedir. Bal, 2011 yılında yaptığı çalışmada tarih ögretmen adaylarının program bilgilerinde eksiklikler olduğunu, teorik olarak yöntem ve teknikleri bildikleri ancak derse uygulamada zorlandıklarını, öğrenci zorluklarını anlamada güçlük çektiklerini ve yeni programın önerdiği ölçme değerlendirme tekniklerini kullanma konusunda eksikliklerinin olduğunu belirtmiştir. Yıldız ise konuyla ilgili çalışmasında tarih öğretmenlerinin öğrenci merkezli öğretim anlayışından uzak oldukları sonucuna ulaşmıştır (2010: 71). Bu nedenle analoji, müze ve alan gezileri, simülasyon, internet, yazıl1 ve görsel materyaller, sözlü tarih çalışmaları, arkeolojik kalıntılar, fotoğraflar, tablolar gibi öğrenci merkezli öğretim anlayışına uygun yöntem ve malzemeler sosyal ve kültürel konuların öğretiminde işe koşulmalıdır. Bu tip çabalar tarihsel bilgi, belge ve malzeme ile karşılaşan öğrencilerin bilgiyi içselleştirmelerine ve ezbercilikten kurtulmalarına yardımcı olabilir. Böylece tarih öğretmenlerinin öğrenci merkezli yöntemlere inanarak hayata geçirmeleri başarıyı artırabilir.

\section{SONUÇ VE ÖNERILER}

Postmodernist yaklaşımların tarih eğitimi üzerindeki etkisi ile tarih eğitiminin içeriği ve amaçları konusundaki düşünceler son yıllarda değişikliğe uğramıştır. Tarih öğretiminde siyasi tarihten öteye geçmenin gerekli olduğu düşünülürken tarih derslerinde öğrencinin zihnen ve bedenen aktif olduğu öğrenciyi merkeze alan yöntemler önem kazanmıştır. Tarih öğretiminin en önemli amaçlarından biri de çocuğu içinde yaşadığı sosyal ve kültürel hayat hakkında aydınlatmasıdır. Tarih öğretimi geçmişten yola çıkarak günümüze ulaşmalı ve günümüzü anlamada, yorumlamada öğrenciye yol gösterici olmalıdır. Muhakkak ki geçmişi ve günümüzü değerlendirebilen bireyler geleceğe daha bilinçli bakabilecektir. Öğrencileri içinde yaşadıkları zaman ve mekan konusunda aydınlatırken tarihe çok yönlü bakmayı ihmal etmemek gerekmektedir. Tarih öğretiminin çok yönlü işlevini unutmak, tarih öğretimini eksik bırakmak anlamına gelecektir. Sadece siyasî tarih ya da sadece iktisadî tarih, bireyin sosyal hayatı anlaması ve tarih becerilerini kazanması için yeterli değildir. Sosyal ve kültürel konuların öğretilmesi öğrencilere hayata karşı çok boyutlu bir bakış açısı kazandırma süreci açısından oldukça önemlidir. 
Tarih öğretimine yönelik beklentilerin değişmesi, programları etkilemektedir. Pedagojik kaygılar ise, yöntem sorununu tartışma platformuna çekmektedir. Ancak tarih öğretiminin yeniden yapılandırılması sürecinde sosyal ve kültürel konuların öğretimi zihinleri meşgul eden bir konudur. Öyleyse tarih öğretiminde sosyal ve kültürel konuların etkili bir şekilde öğretilmesi için:

- Yenilenen tarih öğretim programlarında sosyal ve kültürel konuların program içerisindeki diğer konularla birlikte dağılımının dengeli yap1lmas1,

- Değişen programın uygulanabilmesi için öğretmen ve öğrencilere sosyal ve kültürel konuların öğretimi ile ilgili gerekli eğitimin ve desteğin verilmesi,

- Öğretmenlerin tarih öğretiminin değişen amaçları ve tarih ders programları hakkında değişikliklere bağlı olarak bilgilendirilmesi,

- Özellikle milli eğitim sisteminden kaynaklanan sınıf dişı eğitimin önündeki yasal ve yasal olmayan engellerin ilgili birimler tarafından kaldırilması,

- Öğretmenlere, sosyal ve kültürel konuların öğretilebilmesi noktasında kolaylık sağlayan eğitim araç-gereçlerinin sağlanması,

- Öğrencilerin derslerde sosyal ve kültürel konularla yüz yüze getirilmesi,

- Uygun seçilmiş terimlerle öğrencilere, günümüzdeki bazı sosyal ve kültürel konularla geçmişteki aynı konuları karşılaştırma imkânı verilmesi,

- Tarih dersi ile sosyal ve kültürel konuların ilişkilendirildiği araştırmalardan faydalanılması,

- Öğretim programlarında sosyal ve kültürel konulara ilişkin başlıklar yeterince yer almıyorsa, siyasi tarih konularının işlenişinde öğrencilerin dikkatlerinin ilgili dönemdeki sosyal ve kültürel konulara çekilmesi (örn: Osmanlı tarihinde bir padişahın seferi anlatılırken, saraydaki sefer hazırlıkları, sefere çıkış töreni, halkın orduyu uğurlaması, padişah çadırlarının/otağlarının kurulması vb. kültürel konulara değinilebilir) gerekmektedir. 


\section{KAYNAKLAR}

Akçura, Y. (1932), "Tarih Yazmak ve Tarih Okutmak Usullerine Dair”, Birinci Türk Tarih Kongresi Konferans Müzakere Zabitları. s. 577 - 607. http://www.yachtworks.info/tr/akcura.html\#2 adresinden 3 Şubat 2012 tarihinde elde edilmiştir.

Ata, B. (2008), "Türk Tarih Öğretmen Adaylarının Tarih Eğitiminde Analoji Anlayışları", 21. Yüzyılda Kimlik, Vatandaşlık ve Tarih Eğitimi, Ankara: Yeni İnsan Yayınları.

Ata, B. (2002), Müzelerle Ve Tarihî Mekanlarla Tarih Öğretimi: Tarih Öğretmenlerinin "Müze Eğitimine” İlişkin Görüşleri, Yayınlanmamış Doktora Tezi, Gazi Üniversitesi Sosyal Bilimler Enstitüsü, Ankara.

Bailey, T. (2008), Civil War. New York: Scholastic.

Bal, M. S. (2011), "Tarih Öğretmen Adaylarının Haçlı Seferleri Konusunda Pedagojik Alan Bilgilerinin İncelenmesi”, Selçuk Üniversitesi Ahmet Keleşoğlu Eğitim Fakültesi Dergisi, 31: 239-261.

Barton, K. C. and L. S. Lewstik (2004), Teaching History For The Common Good, New Jersey: Lawrence Erlbaum Associates.

Bilgin, N. (1995), “Kimlik Arayışı Olarak Resmi Tarih”, Tarih Öğretimi ve Ders Kitapları, Yay. Haz: Salih Özbaran, İstanbul, Tarih Vakfı Yurt Yayınları.

Çapa, M. (2009). "Sosyal Bilim Disiplinleri - Tarih", Sosyal Bilgilerin Temelleri, Editör: Ali Sinan Bilgili, Ankara: Pegem Akademi Yayınevi.

Demircioğlu, İ. H. (2007), Tarih Öğretiminde Öğrenci Merkezli Yaklaşımlar, (2. bask1), Ankara, An1 Yayınc1l1k.

Demircioğlu, İ. H. (2010), "Tarih Öğretiminin Amaçları”, Tarih Nasıl Öğretilir, (1. bask1), Editör: Mustafa Safran, İstanbul: Yeni İnsan Yayınları.

Deveci, H. (2009), "Sosyal Bilgiler Dersinde Kültürden Yararlanma: Öğretmen Adaylarının Kültür Portfolyolarının İncelenmesi”, Elektronik Sosyal Bilimler Dergisi, Cilt: 8, 28: 1-19.

Di Giacomo, R. (2009), Short Role-playing Simulations for World History Classrooms, San Jose: Magnifico Publications.

Dilek, G. (2001), "Çağdaş Tarih Öğretimi Programlarında Temel Yaklaşımlar”, Tarih Nasıl Öğretilir, Editör: Mustafa Safran, İstanbul: Yeni İnsan Yayınları. 
Dilek, D. (2001), “İlköğretimde Tarih Konularının Öğretiminde Kullanılan Tekniklere Göre Öğretmen Tipleri”, Kuram ve Uygulamada Eğitim Bilimleri, Cilt I, 2: 326-336.

Dilek, D. (2002), Tarih Derslerinde Öğrenme ve Düşünce Gelişimi, Ankara: Pegem Akademi Yaymevi.

Fischer, M. W. (1993), World History Simulations, Huntington: Teacher Created Materials.

Halkın, L - E. (2000), Tarih Tenkidinin Unsurları, (Çev. B. Yediyıldız), (2. Baskı), Ankara: Türk Tarih Kurumu Basımevi.

Hobsbawn, E. J. (1985), "Toplumsal Tarihten Toplumun Tarihine”, Tarih ve Tarihçi. (Der. Ali Boratav), (1. Baskı), İstanbul: Alan Yayıncılık.

Karabağ, Ş. G. (2002), "Postmodernizm ve Tarih Öğretimi”, Türk Yurdu Dergisi, Cilt 22, 175: 61-67.

Keskin, S. (2008), Romanlarla Tarih Eğitimi ve Öğretimi, Yayınlanmamış Yüksek Lisans Tezi, Selçuk Üniversitesi Sosyal Bilgiler Öğretmenliği Bilim Dal, Konya.

Komisyon. (2007), Tarih 1 Ders Kitab1, Ankara: MEB.

Komisyon. (2011), Tarih Ders Kitabı, Ankara: MEB.

Köse, M. (2004), Tarih Öğretiminde Kadın ve Türk Kadını İmajı. Yayımlanmamış Yüksek Lisans Tezi. Gazi Üniversitesi Eğitim Bilimleri Enstitüsü, Ankara.

Köstüklü, N. (2001), Sosyal Bilimler ve Tarih Öğretimi, (3. Bask1), Konya: Günay Ofset.

Meb, (2012), İlköğretim Sosyal Bilgiler 6-7. Sınıf Öğretim Programı. http://ttkb.meb.gov.tr/program.aspx adresinden 29 Ocak 2012 tarihinde elde edilmiştir.

Ortaylı, İ. (2007), "Tarih Öğretimi İçin Yazılacak Kitaba İlişkin Sorunlar", Tarih Öğretimi ve Ders Kitapları, İstanbul: Tarih Vakfı Yurt Yayınları.

Safran, M. (2002), “Türk Tarihi Öğretimi ve Meseleleri”, Türkler Ansiklopedisi, Cilt 17, Ankara: Yeni Türkiye Yayınları.

Safran, M. (1996), “Tarih Programları Nasıl Düzenlenmelidir?”, GÜGEF Dergisi, 4.

Safran, M. (2006), Tarih Eğitimi, Ankara: Gazi Kitabevi.

Senemoğlu, N. (2002), Gelişim, Öğrenme ve Öğretim, Ankara: Gazi Kitabevi.

Sönmez, V. (2008). Eğitim Felsefesi. (8. baskı). Ankara: Anı Yayıncılık. 
Stradling, R. (2003), 20. Yüzyıl Avrupa Tarihi Nasıl Öğretilmeli, İstanbul: Tarih Vakfi Yayınları.

Şimşek, A. (2006), “Türkiye'deki Sosyal Bilgiler Öğretimi Alanı Çocuk Edebiyatı Ürünlerinden Yararlanma Bağlamında Çağdaş Dünyanın Neresindedir?" (4-6 Ekim), II. Ulusal Çocuk ve Gençlik Edebiyatı Sempozyumu, Ankara Üniversitesi Eğitim Bilimleri Fakültesi, Ankara.

Şimşek, A. (2007), "Türkiye'de Tarih Eğitiminin Ulusallığı ve Avrupa Merkezcilik", Türkiye Sosyal Araştırmalar Dergisi, Y11: 11, 1.

Tekeli, İ. (2002), Yaratıcı ve Çağdaş Bir Tarih Eğitimi İçin, İstanbul: Tarih Vakfi Yayınları.

URL 1. (2001), 21. Yüzyıl Avrupa'sında Tarih Öğretimi. Avrupa Konseyi Bakanlar Komitesi'nin Rec (2001)15 No'lu Tavsiye Kararı. http://digm.meb.gov.tr/belge/AK_Tarih21yy.htm adresinden 21 A ğustos 2011 tarihinde elde edilmiştir.

Yıldız, A. (2010), Tarih Öğretmeni Tipleri ile Sınıfa Yansıyan Tarih Anlayışı Arasındaki İlişkinin Değerlendirilmesi, Yayımlanmamış Doktora Tezi, Gazi Üniversitesi Eğitim Bilimleri Enstitüsü, Ankara. 